\title{
GRAIN QUALITY OF WINTER RYE CULTIVARS GROWN IN LATVIA
}

\author{
Daiga Kunkulberga $^{1 *}$, Anda Linina ${ }^{2}$, Arta Kronberga ${ }^{3}$, Aina Kokare ${ }^{3}$, Inga Lenenkova ${ }^{1}$ \\ ${ }^{1}$ Department of Food technology, Faculty of Food Technology Latvia University of Agriculture, Rigas iela 22, Jelgava, Latvia, \\ e-mail:daiga.kunkulberga@llu.lv \\ ${ }^{2}$ Institute of Agrobiotechnology, Faculty of Agriculture, Latvia University of Agriculture, Liela iela 2, Jelgava, Latvia \\ ${ }^{3}$ Institute of Agricultural Resources and Economics, Zinatnes iela 2, Priekul,i, Latvia
}

\begin{abstract}
Rye (Secale cereale L.) has been cultivated in Europe since ancient times and is second only to wheat among the grains most commonly used in the production of bread. Rye is traditionally consumed as wholemeal products in Baltic countries. In Latvia, rye bread is rich with traditions, and is one of the more favourite types of bread. Our objectives were to determine the grain quality and suitability of the most popular winter rye cultivars in Latvia for wholegrain flour production and bread baking. Three population winter rye cultivars 'Kaupo', 'Amilo', 'Dankowskie Amber' and three hybrid rye cultivars 'Brasetto F1', 'Su Drive F1', 'Su Mephisto F1' were obtained from research field trials (2014 / 2015, 2015/2016) at the Priekuli Research Centre, Institute of Agricultural Resources and Economics in Latvia and used for evaluation. Rye grain quality indices were analysed at the Latvia University of Agriculture, in Grain and Seed Research laboratory. Average data in our investigation (two years) show that cultivar, environment and cultivar $\times$ environment interaction significantly $(\mathrm{p}<0.05)$ affected 1000 kernel weight, volume weight, protein content, starch content and Hagberg falling number. The thousand kernel weight in hybrids cultivars grains was statistically significantly higher comparing population cultivar grains. Differences between hybrids cultivars grains volume weight, protein content, falling number comparing with population cultivar grains was not observed. The results of the current research show that the quality of all the studied cultivars meet the requirements for high-grade rye grains for food consumption and are suitable for the wholegrain flour production and bread baking.
\end{abstract}

Keywords: winter rye, grain quality, varieties.

\section{Introduction}

Winter rye (Secale cereale L.) is one of the most important bread grains in colder parts of Europe. The chemical composition of rye grain promises health benefits and it contributes to higher intake of dietary fibre. Grain quality adversely affects price and consumer acceptance of finished products (Hansen et al., 2004).

Quality indices of winter rye are not stable between production years because of the inconsistency of the variables, such as initiation of the growing season, distribution of rainfall and heat units available for crop growth during corresponding phases of plant growth and development (Hansen et al., 2004). During ripening rye needs sunny and warm weather and moderate moisture. These conditions secure biological maturity and acceptable technological properties of grain (Kunkulberga et al., 2007; Stepien et al., 2016).

The volume weight is used as an index of rye grain quality, and minimum volume weight requirement for food grain grown in Latvia is $700 \mathrm{~g} \mathrm{~L}^{-1}$. The 1000 kernel weight depends on grain density and size and the 1000 kernel weight of rye grain in Latvia is about $44 \mathrm{~g}$ (Tupits, 2008; Jansone, 2015), while in Lithuania - between $33.5 \mathrm{~g}$ and $38.3 \mathrm{~g}$ (Vidmantiene, Joudeikiene, 2010). The kernel weight was negative influenced by high temperature and drought during the ripening stage (Shmielwski, Koln 2000).

The main chemical constituents of rye grain are starch and protein. The starch content is limited mainly to the endosperm, and contents between $57 \%$ and $66 \%$ of dry mater are reported in rye growing in Poland (Hansen et al., 2004), while in investigation grown in Latvia between 53\% and 63\% (Mal̦ecka, Strazdiña, 2004; Jansone, 2015). The content of protein reported in rye cultivars, grown in different countries, was between 7.0 and 14.6\% (Hansen et al., 2004; Banu, 2006; Ruzgas, Plycevaitiene, 2005; Zdubel et al., 2009; Jansone, 2015).

The baking quality of rye is mainly affected by the activity of amylases measured as Hagberg falling number (hereinafter falling number). It is well known in the milling and baking industry that quality of rye flour can be highly different from one year to another because the amylases activity is significantly affected by the temperature and amount of rain during growing season (Salmenkallio-Marttila, Hovineen, 2005).

Cereal grain is of the highest quality during growth period between wax maturity and full maturity. During this period cereal yield forming is already finished and, in case of unfavourable weather conditions, grains can start sprouting, which would result in reduced falling number. Under very wet harvesting conditions rye reaches the limit when $\alpha$-amylase activity is considered to be too high. Emergence of grain sprouting may also affect the dormancy period. Grain dormancy period is depending on the weather conditions in grain formation and ripening phase. The falling number value depends on the cultivar genetic characteristics (Ingver, 2002); Malecka, Strazdina, 2004)

If the falling number is $65 \mathrm{~s}$, the volume of bulk bread decreased, while the middle value of falling number (150 s) did not affect the bread volume (Dvorakova et al., 2010). In Latvia the minimum falling number requirement for food rye grain is $130 \mathrm{~s}$ (GmbH Dobeles..., 2016). A falling number that is too low results in pasty and unacceptable bread (Hansen et al., 2004).

The objective of the research was to determine the rye grain quality and suitability of the most popular rye cultivars in Latvia for wholegrain flour production. 


\section{Materials and Methods}

Study fields

Field investigation in years 2014/2015 and 2015/2016 was conducted at the Priekuli Research Centre, Institute of Agricultural Resources and Economics (Latvia), on the soil of sod-podzoloic loam with close to neutral acidity $\left(\mathrm{pH}_{\mathrm{KCl}}\right.$ 5.6-6.0), medium high phosphorus and potassium, humus content $1.7-2.5 \mathrm{~g} \mathrm{~kg}^{-1}$.

There were winter rye cultivars of three populations ('Kaupo' (Latvia), 'Amilo' (Poland), 'Dankowskie Amber' (Poland)) and three cultivars of hybrid winter rye ('Brasetto F1', 'Su Drive F1', 'Su Mephisto F1' (all Germany)) examined during research. These cultivars in Latvian farms nowadays are popular. The field experiment was placed randomly in four replications. Nitrogen, phosphorus and potassium fertilizers $(6: 26: 30)$ were applied in autumn. Nitrogen $(\mathrm{N})$ was applied $\mathrm{N} 68 \mathrm{~kg} \mathrm{ha}^{-1}$ in spring after resumption of vegetative growth and $\mathrm{N} 31 \mathrm{~kg} \mathrm{ha}^{-1}$ at the tillering stage. Grain was harvested at full ripeness; sampling procedure for grain quality evaluation was performed according to the standard ICC 101/1 for obtaining average sample.

\section{Weather data collection}

Winter rye sown in 2014 and 2015 overwintered successfully. The air temperature in investigation years (Table 1) in April was close to long-term average observations. May in 2015 was by $-1.5^{\circ} \mathrm{C}$ colder, while in 2016 was by $2.7^{\circ} \mathrm{C}$ warmer, which promoted plant growth and development. Average daily temperature in June 2015 was lower by $0.6^{\circ} \mathrm{C}$ compared to long-term average data, in 2016 air temperature was warmer by $1.5^{\circ} \mathrm{C}$ witch contributed to the accumulation of protein. Temperature in the grain filling period (July), which is the most decisive for grain quality formation, was in 2015 by $1.6^{\circ} \mathrm{C}$ colder, while in 2016 by $0.4{ }^{\circ} \mathrm{C}$ higher than the long-term average mean data.

Table 1

Weather conditions during the field investigation

\begin{tabular}{|c|c|c|c|}
\hline \multirow{2}{*}{ Month } & \multicolumn{3}{|c|}{ Average temperature, ${ }^{\circ} \mathrm{C}$} \\
\hline & 2015 & 2016 & LTM* \\
\hline April & 5.4 & 6.1 & 4.6 \\
\hline May & 10.2 & 14.5 & 11.0 \\
\hline June & 14.3 & 16.4 & 14.8 \\
\hline July & 15.9 & 17.9 & 16.9 \\
\hline \multirow[t]{2}{*}{$\begin{array}{l}\text { Monthly } \\
\text { average }\end{array}$} & 11.5 & 13.7 & 11.8 \\
\hline & \multicolumn{3}{|c|}{ Sum of precipitation, $\mathbf{m m}$} \\
\hline April & 76 & 82 & 40 \\
\hline May & 53 & 10 & 56 \\
\hline June & 39 & 145 & 78 \\
\hline July & 92 & 110 & 93 \\
\hline $\begin{array}{l}\text { Monthly } \\
\text { average }\end{array}$ & 65 & 87 & 67 \\
\hline
\end{tabular}

Water availability has effect on rye grain quality. Precipitation in April 2015 and 2016 was respectively by $212 \%$ and $232 \%$ more than long-term mean data.

May in 2015 and 2016 was dry. Precipitation in June 2015 was close to the long-term mean, while in 2016 by $178 \%$ more than the long-term mean data. Precipitation in July 2015 by $127 \%$ exceeded the longterm average data, in 2016 close to long-term average observations.

\section{Analysis}

The rye grains were analysed at the Latvia University of Agriculture in Grain and Seed Research laboratory. Quality parameters: protein content (\%), starch content (\%) and volume weight $\left(\mathrm{g} \mathrm{L}^{-1}\right)$ were analysed by grain analyser Infratec 1241 (Sweden), which employs the near-infrared analysis within the wavelength range 570-110 nm. Thousand kernel weight determined by LVS EN ISO 520 „Cereals and pulses. Determination of the mass of 1000 grains", this was done by counting 500 grains duplicate with a counter „Contador”. The Hagberg falling number $-\alpha$-amylase activity - was measured by the Hagberg-Perten method using a Perten Instruments (Sweden) „Falling number 1500” assessed according to LVS EN ISO 3093 using $7 \mathrm{~g}$ of flour adjusted for moisture content to $15 \%$.

\section{Statistical analysis}

Experimental data evaluation was done using two factor analysis of variance by Fisher's criteria and least significant difference (LSD $\left.{ }_{0.05}\right)$ were applied to estimate the effects of year (meteorological conditions) and cultivars. Component of variance ANOVA for each quality characteristic were expressed as percentage to illustrate the relative impact of each source to the total variance. Differences of the grain quality indices between population and hybrid rye cultivars determined by t-Test: Two Sample Assuming Unequal variance. Correlation analysis between starch content and other grain quality indices, also between protein content and other grain quality indices was carried out.

\section{Results and Discussion}

In this study the rye grain yield of the cultivars was between 5.1 to $7.8 \mathrm{t} \mathrm{ha}^{-1}$. Average data in our experiment ( 2 years) determined by t-Test suggest that grain yield from hybrids cultivar was statistically significantly higher comparing population cultivar $\left(\mathrm{t}_{\text {stat. }} 3.33>\mathrm{t}_{\text {crit. }}\right.$ 2.92).

\section{Grain characteristics}

Grain qualities of the different cultivars are differing. Thousand kernel weight (TKW) varied significantly ( $>0.05$ ) depending on the cultivars and meteorological conditions. Average 1000 kernel weight was $42.4 \pm 0.6 \mathrm{~g}, \mathrm{~V}=5.0 \%$ (Table 2).

The 1000 kernel weight ranged from $39.7 \mathrm{~g}$ ('Kaupo') to $44.6 \mathrm{~g}$ ('Su Drive') on average (Table 2). Similar results were obtained in Lithuania (Alijošius et al., 2016) where in seven rye varieties average of 1000 grains weight were $43.9 \mathrm{~g}$. 
Table 2

Winter rye quality indices

\begin{tabular}{|c|c|c|c|c|}
\hline Quality indices & Mean & $\min$ & $\max$ & $\mathrm{V} \%$ \\
\hline TKW, g & $42.4 \pm 0.6$ & 38.9 & 46.7 & 5.0 \\
\hline $\mathrm{VW}, \mathrm{g} \mathrm{L}^{-1}$ & $754.0 \pm 3.8$ & 737.0 & 779 & 1.8 \\
\hline $\mathrm{PC}, \%$ & $10.1 \pm 0.7$ & 7.7 & 13.1 & 22.5 \\
\hline $\mathrm{SC}, \%$ & $61.8 \pm 0.7$ & 58.8 & 64.8 & 4.1 \\
\hline FN, s & $212.0 \pm 13.0$ & 133.0 & 305 & 21.2 \\
\hline \multicolumn{5}{|c|}{$\begin{array}{l}\text { TKW - } 1000 \text { kernel weight, VW - volume weight, } \\
\text { PC - protein content, } \mathrm{SC} \text { - starch content, FN - falling } \\
\text { number }\end{array}$} \\
\hline \multirow{2}{*}{\multicolumn{5}{|c|}{$\begin{array}{l}\text { In our investigation, the } 1000 \text { kernel weight was highly } \\
\text { influenced by cultivar (69\%) and cultivar } \times \text { year }(19 \%) \text {, } \\
\text { while influence of harvest year was smaller }(10 \%) \text {, } \\
\text { however in Hansen and colleagues (2016) experiments } \\
1000 \text { kernel weight dependency on year complete to } \\
65 \% \text { but the influence of cultivar }-25 \% \text {, whole } \\
\text { cultivar } \times \text { year }-5 \% \text { (Tab. } 3) \text {. } \\
\text { Table } 3\end{array}$}} \\
\hline & & & & \\
\hline Cultivar & 2015 & 2016 & \multicolumn{2}{|c|}{ Average } \\
\hline Dank. Amber & 40.8 & 43.2 & \multicolumn{2}{|c|}{42.0} \\
\hline Kaupo & 38.9 & 40.5 & \multicolumn{2}{|c|}{39.7} \\
\hline Amilo & 41.0 & 41.5 & \multicolumn{2}{|c|}{41.2} \\
\hline Brasetto & 42.1 & 46.7 & \multicolumn{2}{|c|}{44.4} \\
\hline SU Drive & 44.9 & 44.3 & \multicolumn{2}{|c|}{44.6} \\
\hline SU Mephisto & 42.7 & 42.1 & \multicolumn{2}{|c|}{42.4} \\
\hline Average & 41.7 & 43.0 & \multicolumn{2}{|c|}{42.4} \\
\hline
\end{tabular}

Average data in our experiment (2 years) determined by t-Test suggest that thousand kernel weight in hybrids cultivar was statistically significantly higher comparing population cultivar $\left(\mathrm{t}_{\text {fac. }} 2.91>\mathrm{t}_{\text {crit. }}\right.$ 2.13).

Table 4

Impact factors of rye grain quality indices, \%

\begin{tabular}{lccccc}
\hline Source of variation & TKW & VW & PC & SC & FN \\
\hline Year & 10 & 66 & 96 & 95 & 42 \\
Cultivar & 69 & 15 & 2 & 3 & 44 \\
Year $\times$ cultivar & 19 & 16 & 2 & 2 & 14
\end{tabular}

TKW - 1000 kernel weight, g, VW - volume weight, g L ${ }^{-1}$, $\mathrm{PC}$ - protein content, \%, SC - starch content, $\%, \mathrm{FN}$ - falling number, $\mathrm{s}$.

The volume weight $(V W)$ in winter rye grain (Table 5) ranged from $753 \mathrm{~g} \mathrm{~L}^{-1}$ ('Dankowskie Amber') to $764 \mathrm{~g} \mathrm{~L}^{-1}$ ('Su Mephisto').

Table 5

Rye grain volume weight, $\mathrm{g} \mathrm{L}^{-1}$

\begin{tabular}{lccc}
\hline \multicolumn{1}{c}{ Cultivar } & $\mathbf{2 0 1 5}$ & $\mathbf{2 0 1 6}$ & Average \\
\hline Dank. Amber & 760 & 746 & 753 \\
Kaupo & 754 & 743 & 748 \\
Amilo & 773 & 749 & 761 \\
Brasetto & 764 & 749 & 756 \\
SU Drive & 779 & 737 & 758 \\
SU Mephisto & 774 & 753 & 764 \\
\hline Average & 767 & 746 & 757 \\
\hline
\end{tabular}

Average data show that the volume weight for cultivars mean \pm standard error was $754 \pm 3.8$ the coefficient of variation was $1.8 \%$. The content of volume weight measured in this study is in accordance with findings by other authors (Jansone, 2015; Hansen et al., 2016).

The volume weight was highly influenced by harvest year $(66 \%)$ and cultivar $\times$ year $(16 \%)$, cultivar influence was small (2\%) (Table 4). Influence of the year was most remarkable also in the investigation with 19 winter rye cultivars in the three years 2004-2007 in Denmark (Hansen et al., 2016).

\section{Chemical composition}

The content of protein and starch belongs to important criteria for the quality of cereals (Stepien et al., 2016).

In our investigation grain protein content, starch content and falling number significantly $(\mathrm{p}<0.05)$ varied depending on the cultivars and meteorological conditions. The protein content $(P C)$ ranged from $9.7 \%$ ('SU Mephisto') to $10.4 \%$ ('Dankowskie Amber'). The content of protein in rye grain was differentiated by weather conditions in years. Nowotna et al. (2006) showed that the average content of protein (for five test cultivars of winter rye) is $9.6 \%$, while the investigation of west Lithuania region indicates a broader range of protein content from 9 to $19 \%$ (Skuodiene, Nekrošeine, 2009).

Table 6

Rye grain protein content, $\%$

\begin{tabular}{lccc}
\hline Cultivar & $\mathbf{2 0 1 5}$ & $\mathbf{2 0 1 6}$ & Average \\
\hline Dank. Amber & 8.7 & 12.2 & 10.4 \\
Kaupo & 7.7 & 12.3 & 10.0 \\
Amilo & 7.8 & 13.1 & 10.5 \\
Brasetto & 8.4 & 12.2 & 10.3 \\
SU Drive & 7.7 & 12.1 & 9.9 \\
SU Mephisto & 7.7 & 11.6 & 9.7 \\
\hline Average & 8.0 & 12.3 & 10.1 \\
\hline
\end{tabular}

Data in our experiment (2 years) suggest that protein content was significantly $(\mathrm{p}<0.05)$ influenced by harvest year $(96 \%)$, while cultivar and cultivar $\times$ year influence was small (2\%) (Table 4). However in Danish (Hansen et al., 2016) experiments protein content in rye grain dependency on cultivar complete to $67 \%$, the influence of year $-17 \%$ but cultivar $\times$ year influence was small $-4 \%$.

In 2016 harvest year the content of protein in rye grains was higher by $4.3 \%$ as compared with the 2015 year. In the 2016 with a higher mean air temperature in summer favoured a greater concentration of protein. Similar dependences of protein accumulation on weather conditions were confirmed by the study of (Stepien et al., 2016).

The average starch content (SC) (Table 7) in two investigation years of the six cultivars was $58.8 \%$; it ranged from $60.9 \%$ ('Brasetto') to $62.2 \%$ (' $\mathrm{Su}$ Mephisto'). The content of starch measured in this study is in accordance with findings by other authors (Hansen et al., 2004; Ruzgas, Plycevaitiene, 2005; Jansone, 2015).

The starch content was significantly $(\mathrm{p}<0.05)$ influenced by year (94\%), while cultivar influence and 
cultivar $\times$ year influence was small, respective $3 \%$ and $2 \%$.

Table 7

Rye grain starch content, \%

\begin{tabular}{lccc}
\hline Cultivar & $\mathbf{2 0 1 5}$ & $\mathbf{2 0 1 6}$ & Average \\
\hline Dank. Amber & 64.4 & 59.7 & 62.1 \\
Kaupo & 64.8 & 59.3 & 62.1 \\
Amilo & 64.3 & 58.8 & 61.5 \\
Brasetto & 63.1 & 58.8 & 60.9 \\
SU Drive & 64.1 & 59.6 & 61.8 \\
SU Mephisto & 64.1 & 60.2 & 62.2 \\
\hline Average & 64.1 & 59.4 & 61.8 \\
\hline
\end{tabular}

Falling number $(F N)$ is an indication of degree of soundness of rye in terms of freedom from sprouting (Ingver et al., 2002) which causes the production and activation of $\alpha$-amylase inside the rye kernel which, in its turn, has a very drastic effect on the dough and bread making process. In our investigation the falling number of grain was significantly $(\mathrm{p}<0.05)$ different for cultivars. Average data show that the falling number for cultivars was $212 \pm 13.0 \mathrm{~s}$, range min $-\max$ 130-305 s, the coefficient of variation was $21.2 \%$ (Table 2). The falling number of six grain samples ranged from $133 \mathrm{~s}$ ('Kaupo') to $254 \mathrm{~s}$ ('Amilo') (Table 8). Vidmantiene and Joudeikiene, (2010) also confirmed that the falling number of different cultivars may vary in the same growing conditions.

Weather conditions in investigation years influenced grain $\alpha$-amylase activity. Higher falling number for all rye cultivars was observed in 2014/2015 (214-305 s). Those were higher comparing to 2015/2016 (133-222s). The falling number was affected by precipitation during grain maturation. High rainfall in grain maturation period resulted in higher $\alpha$-amylase activity and lower falling number (Tupits, 2008). In our investigation in July 2016 during rye grain maturation the rainfall exceeded the long-term mean data.

Table 8

Rye grain falling number, $s$

\begin{tabular}{lccc}
\hline \multicolumn{1}{c}{ Cultivar } & 2015 & 2016 & Average \\
\hline Dank. Amber & 229 & 222 & 226 \\
Kaupo & 208 & 133 & 170 \\
Amilo & 305 & 203 & 254 \\
Brasetto & 266 & 205 & 235 \\
SU Drive & 221 & 158 & 190 \\
SU Mephisto & 214 & 189 & 202 \\
\hline Average & 240 & 185 & 213 \\
\hline
\end{tabular}

The falling number was similarly influenced by year $42 \%$ and cultivar - 44\%, whereas the effect of cultivar $\times$ year accounted for $14 \%$ (Table 4 ), however in Hansen et al. (2016) experiments falling number dependency on year completed to $77 \%$ but the influence of cultivar $11 \%$, cultivar $\times$ year $-8 \%$.

\section{Correlations}

A statistically significant positive correlation was found between starch content and falling number $\mathrm{r}=0.594$ and volume weight $\mathrm{r}=0.791 \quad(\mathrm{n}=12$, $\left.r_{0.01}=0.576, r_{0.05}=0.708\right)$, which is in accordance with results obtained in Lithuania (Ruzgas, Plycevaitiene, 2005). Negative correlation was found between protein content and volume weight $r=-0.839$ (Figure 1).

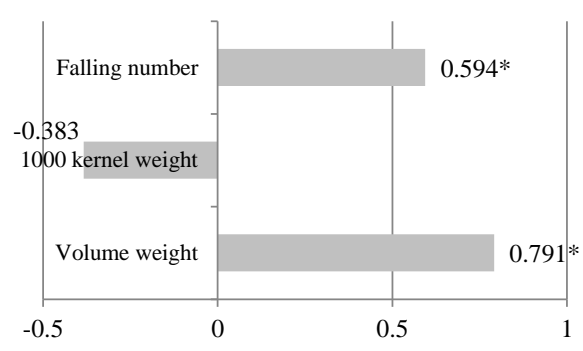

\section{Figure 1. Correlation coefficient (r) between starch content and other quality indices $\mathrm{r}^{*}$ - is significant at $95 \%$ level probability}

Protein content showed high negative relationship between starch content $(r=-0.981)$, what in the present experiment was confirmed in Lithuania also (Ruzgas, Plycevaitiene, 2005). Protein content significant negative correlated between volume weight $(\mathrm{r}=-0.839)$, these results are in accordance with the ones described by Hansen et al. (2016). A negative correlation between rye grain protein content and falling number identified in our investigation $(r=0.616)$ was also found by Ruzgas and Plycevaitiene (2005) (Figure 2).

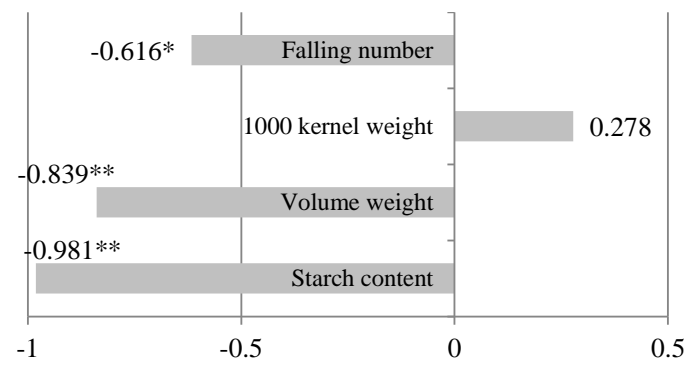

Figure 2. Correlation coefficient (r) between protein content and other quality indices

$\mathrm{r}^{* *}$-significant at $99 \% ; \mathrm{r}^{*}$-significant at $95 \%$ level probability

\section{Conclusions}

The thousand kernel weight in grains of hybrid cultivars was statistically significantly higher comparing to grains of population cultivar.

Differences between hybrids cultivars grains volume weight, protein content, falling number comparing with population cultivar grains were not observed.

Year meteorological conditions had a much stronger effect on rye grain volume weight, protein content, starch content and falling number than cultivar.

The influence of cultivar was confirmed on higher level for winter rye grain protein content compared with the year meteorological conditions. 
The strong negative correlation was found between protein content and falling number, volume weight, and starch content.

The positive correlation was found between starch content and falling number and volume weight.

\section{Acknowledgement}

Research has been supported by the National research programme "Agricultural Resources for Sustainable Production of Qualitative and Healthy Foods in Latvia" (AgroBioRes) (2014-2017), project No. 4 "Sustainable use of local agricultural resources for qualitative and healthy food product development" (FOOD).

\section{References}

1. AS. Dobeles dzirnavnieka 2016. gada graudu pienemšanas prasības (Grain processing company Dobeles dzirnavnieks requirement for grains of acceptance in 2016) [accessed 11.06.2016]. Available at: $\mathrm{http}: / /$ dzirnavnieks.lv/lv/graudu-piegadatajiem (in Latvian)

2. Alijošius S., Švirmickas J., Bliznikas S., Gružauskas R., Šašyte V., Racevičiūte-Stupeliene A., Kliševičiūte V., Daukšiene A. (2016). Grain chemical composition of different varieties of winter cereals. ZemdirbysteAgriculture, Vol. 103, (3), p. 273-280.

3. Banu I. (2006) The evaluation of the quality rye flours on the basis of the biochemical and rheological indices. Journal of Agroalimentary Processes and Technologies, Vol. 12 (2), p. 291-298.

4. Chmielewski F.M., Kohn W. (2000) Impact of weather on yield components of winter rye over 30 years. Agriculture and Forest Meteorology, Vol. 102 (4), p. 253-261.

5. Dvorakova P., Burešova I., Kračmar S., Havlikova R. (2012). Effect of Hagberg Falling number on rye bread quality. Advances in Environment, Biotechnology and Biomedicine, p. 257-260.

6. Hansen H.B., Møller B., Andersen S B, Jørgensen J.R., Hansen A. (2004) Grain characteristics, chemical composition, and functional properties of rye (Secale cereale L.) as influenced by genotype and harvest year.
Journal of Agriculture and Food Chemistry, Vol. 52 (8), p. 2282-2291.

7. Ingver A., Koppel R., Tupits I., Annamaa K. (2002) Sprouting resistance of bread cereals. Zemdirbyste Agriculture, Vol. 78, p. 86-93.

8. Jansone I., Gaile Z. (2015) Heat of winter cereal crops. Research for Rural Development. Vol. 1, p. 40-44.

9. Kunkulberga D., Ruza A., Linina A., Galoburda R. (2007). Evaluation of wholegrain flour baking properties depending on variety. Food Chemistry and Technology, Vol. 41 (2), p. 24-29.

10. Maļecka S., Strazdiņa V. (2004) Rudzu šķirņu produktivitāte un graudu kvalitāte. Agronomijas vēstis Vol.6, p. 40-46.

11. Nowotna A., Gambus H., Liebhard P., Praznik W. Ziobro R., Berski W., Krawontka J. (2006) Characteristic of carbohydrate fraction of rye varieties. Acta Sci. Pol., Technol. Aliment., Vol. 6 (1), p. 87-96.

12. Ruzgas V., Plycevaitiene V. (2005) Activity of alphaamylase in rye grain and its relationship with other traits. Latvian Journal of Agronomy, Vol. 8. p. 162-165.

13. Salmenkallio-Marttila M., Hovineen S. (2005) Enzyme activities, dietary fibre components and rheological properties of wholemeal flours from the cultivars grown in Finland, Journal of Cereal Science of Food Agriculture, Vol. 85, p. 1350-1356.

14. Skuodiene R., Nekrošeine R. (2009). Effect of preceding crops on the winter cereal productivity and diseases incidence. Acta Agriculturae Slovenica, Vol. 93 (2), p. $169-179$.

15. Stepien A., Wojtkoviak K., Pietrusewicz M., Sklodowski M., Pietrzak-Fiečko (2016) The yield and grain quality of winter rye (Secale cereale L.) under the conditions of foliar fertilization with micronutrients $(\mathrm{Cu}, \mathrm{Zn}$ and $\mathrm{Mn})$. Polish Journal of Natural Sciences, Vol. 31 (1), p. 33-46.

16. Tupits I. (2008) Yield and quality of winter rye in trials at the Jogeva PBI. Latvian Journal of Agronomy, Vol. 11, p. $165-171$.

17. Vidmantiene D., Joudeikiene G. (2010) Endoxylanase and endoxylanase inhibition activities in the grain of winter rye cultivars. Zemdirbyste-Agriculture, Vol. 97 (1), p. 3-10.

18. Zdubel A., Dubis, B., Laskowski J. (2009) Influence of nitrogen fertilization of rye on falling number protein and ash contents in whole kernel and flour. Acta Agrophysica, Vol. 13 (2), p. 543-553. 